\title{
Effect of Chilling and Photoperiod on Budbreak in Three Hybrid Grape Cultivars
}

\author{
Amir Rezazadeh ${ }^{1,3}$ and Eric T. Stafne ${ }^{2}$
}

ADDITIONAL INDEX WORDs. chilling requirements, daylength, dormancy, Euvitis, interspecific hybrid, Vitis

SuMMARY. The present study assessed the effect of photoperiod on budbreak of cuttings of three interspecific hybrid grape (Vitis) cultivars that had received different chilling hours. Stem cuttings were collected at 100-hour intervals of chilling $(200,300,400,500,600,700$, and 800 hours) from the vineyard and kept in three growth chambers with daylengths of 8, 16, and 24 hours. Another group of cuttings were maintained in a greenhouse with a natural daylength range of $10.5-$ 13 hours [ 8 Dec. 2017 to 4 May 2018 (average $=12$ hours)]. Chilling requirements, days to budbreak, and budbreak rate were determined after plants were exposed to different chilling hours and daylengths. Results of our study demonstrated that the chilling requirements of all three cultivars were adequately reached at 600 hours or more. Increasing chilling exposure from 600 to 800 hours shortened the time to budbreak in all cultivars. Overall, 'MidSouth' had an average budbreak rate of $90 \%$ when receiving at least $\mathbf{6 0 0}$ hours chilling. 'Blanc du bois' and 'Lake Emerald' had $62 \%$ and $65 \%$ average budbreak, respectively. Longer days ( 24 hours) reduced time to budbreak by 14, 6, and 8 days, respectively, in 'Blanc du bois', 'Lake Emerald', and 'MidSouth' at 600 hours chilling. A combination of 24-hour photoperiod and chilling of 600 hours resulted in a maximum budbreak rate of $70 \%, 70 \%$, and $100 \%$ in 'Blanc du bois', 'Lake Emerald', and 'MidSouth', respectively. Our results indicate that breaking dormancy may be controlled by both temperature and photoperiod in these three cultivars.

$\mathrm{M}$ any woody perennial species require a period of low temperatures during dormancy, referred to as "chilling." A chilling requirement allows plants, especially those in temperate zones, to avoid damage during cold winter months. From late summer into fall, shorter photoperiods and decreases in temperature start the process for the plant to enter into endodormancy. Whereas several woody plants respond to both low temperature and photoperiod to start dormancy, it has been demonstrated that grape are able to start dormancy in response to short days only (Fennell and Hoover, 1991a; Salzman et al., 1996; Wake and Fennell, 2000). Buds in endodormancy

Coastal Research and Extension Center, Mississippi State University, Poplarville, MS 39470

The project was founded through a Specific Cooperative Agreement between Mississippi State University and USDA-ARS, supported by the Mississippi Agricultural and Forestry Experiment Station and Mississippi State University Extension Service. This material is based on work that is supported by the National Institute of Food and Agriculture, U.S. Department of Agriculture, Hatch project 1014723, MIS-149192.

${ }^{1}$ Postdoctoral Researcher

${ }^{2}$ Associate Extension and Research Professor.

${ }^{3}$ Corresponding author. E-mail: ar1372@msstate.edu.

https://doi.org/10.21273/HORTTECH04191-18 are inhibited from growing and cannot resume growth even in a warm environment (Londo and Johnson, 2014). However, once buds receive a certain amount of chilling, they will burst if environmental conditions are conducive. For grape, the optimum chilling fulfillment has been reported to occur between 0 and $7^{\circ} \mathrm{C}$ (Dokoozlian, 1999). Lack of chilling can result in delayed budbreak, uneven budbreak, reduced shoots and cluster development, change in fruit ripening, and an overall decrease in vine productivity (Dokoozlian, 1999; Londo and Johnson, 2014). Low-chill cultivars planted in cold winter areas may be subjected to frequent frost damage because chilling requirements are satisfied too early. Chilling requirements vary by species, cultivars, and growing conditions (Arora et al., 2003; Dokoozlian, 1999; Dokoozlian et al., 1995).
Studies suggest that budbreak can be affected by factors other than temperature, such as photoperiod, after bud set (Myking and Heide, 1995). It has been shown that tree species may be responsive to both photoperiod and temperature regarding dormancy induction and budbreak (Li et al., 2002; Welling et al., 2002). One theory is that photoperiod and temperature both stimulate hormones to act in concert (Arora et al., 2003; Heggie and Halliday, 2005 ) and dictate the timing of dormancy release. Hellmers and Hesketh (1974) showed that time to budbreak in loblolly pine (Pinus taeda) seedlings was influenced by both photoperiod and temperature. Short photoperiods may protect dormant buds from possible frost damage (Häkkinen et al., 1998; Heide, 1993a), whereas long photoperiods may mitigate inadequate chilling accumulations by reducing bud sensitivity to warmer temperatures (Häkkinen et al., 1998; Heide, 1993b; SanzPérez et al., 2009). Wareing (1953) concluded that long day is the main factor for induction of budbreak in european beech (Fagus sylvatica) and the amount of chilling has no considerable effect on photoperiod requirement. Caffarra and Donnelly (2011) also showed that photoperiod had an effect on budbreak when the chilling requirement was not fully met in multiple tree species. In many cases, when chilling requirements are fulfilled, plants become sensitive to longer photoperiods as a signal for budbreak (Körner and Basler, 2010). The release from bud dormancy is likely a complicated process involving many factors including temperature and light (Lavee and May, 1997). Because of these complicated factors, field studies may not satisfactorily estimate chilling requirements (Hanninen et al., 2007; Hunter and Lechowicz, 1992); therefore, in this study, we chose to use controlled environments.

In regions with warm winters, inadequate chilling may lead to

\begin{tabular}{llll}
\hline $\begin{array}{l}\text { Units } \\
\begin{array}{l}\text { To convert U.S. to SI, } \\
\text { multiply by }\end{array}\end{array}$ & U.S. unit & SI unit & $\begin{array}{l}\text { To convert SI to U.S., } \\
\text { multiply by }\end{array}$ \\
\hline 0.3048 & $\mathrm{ft}$ & $\mathrm{m}$ & 3.2808 \\
3.7854 & $\mathrm{gal}$ & $\mathrm{L}$ & 0.2642 \\
2.54 & inch $(\mathrm{es})$ & $\mathrm{cm}$ & 0.3937 \\
$\left({ }^{\circ} \mathrm{F}-32\right) \div 1.8$ & ${ }^{\circ} \mathrm{F}$ & ${ }^{\circ} \mathrm{C}$ & $\left({ }^{\circ} \mathrm{C} \times 1.8\right)+32$
\end{tabular}

\footnotetext{
Hortheding $\cdot$ December $201828(6)$
} 
abnormal budbreak; therefore, artificial application of high temperature (e.g., flaming) or chemicals such as hydrogen cyanamide have been shown to be useful for budbreak in grape (Londo and Johnson, 2014). Although using these techniques can reduce budbreak problems, they are expensive and have potential phytotoxicity consequences (Or, 2009). Ultimately, using adapted, low-chill cultivars is the most sustainable practice. In addition, understanding how chilling hour accumulation affects budbreak induction can help grape breeders combat rising temperatures brought on by climate change. It has been estimated that a significant percentage of worldwide grape production is affected by changing climate conditions as it relates to chill accumulation (Hannah et al., 2013).

Regions like the gulf coastal area of the United States with high relative humidity and strong temperature swings during fall, winter, and spring do not have ideal growing conditions to produce the best quality grapes. Old cultivar options are available and new selections are being tested that may improve grape production in the southern United States.

The aim of the study was to assess the effect of photoperiod on budbreak initiation on cuttings that received different chilling hours in three hybrid grape cultivars adapted to the Gulf Coast region of Mississippi.

\section{Materials and methods}

Plant materials. In 2017, dormant grape cuttings from 5 -year-old 'Blanc du bois' [Vitis aestivalis Fla. D6-148 $\times$ Vitis vinifera 'Cardinal' (Mortenson, 1987)], 'Lake Emerald' [Vitis simpsoni 'Pixiola' $\times V$. vinifera 'Golden Muscat' (Stover, 1954)], and 'MidSouth' [Vitis champinii 'DeGrasset' $\times V$. vinifera Galibert 255-5 (Overcash et al., 1981)] vines were collected from the U.S. Department of Agriculture, Agricultural Research Service (USDA-ARS), Thad Cochran Southern Horticultural Laboratory vineyard in Poplarville, MS [lat. $30^{\circ} 85^{\prime} 36^{\prime \prime} \mathrm{N}$, long. $89^{\circ} 49^{\prime} 94^{\prime \prime} \mathrm{W}$, elevation $97 \mathrm{~m}$, USDA hardiness zone $8 \mathrm{~b}$ (U.S. Department of Agriculture, 2018)]. These cultivars were chosen because they are regionally adapted grapes that are resistant to pierce's disease (Xylella fastidiosa). Collection of cuttings started after the first frost of the season on 12 Nov., when plants had received 200 h chilling. Number of chill hours was obtained from a chill hour application developed by the Mississippi State University Extension Service that calculates the approximate number of chill hours by collecting weather data from different weather stations (Stafne and Alexander, 2017). In the present study, we used the chilling hours model (Bennett, 1949; Weinberger, 1950) to quantify chilling hours calculated within the application. In this model, hours between 0 and $7^{\circ} \mathrm{C}$ are being used as the measure of chilling. The reason we used this model is that the optimum chilling fulfillment for grape has been reported to occur between 0 and $7{ }^{\circ} \mathrm{C}$ (Dokoozlian, 1999). For each cultivar, 10 two-node stem cuttings $(\approx 10$ inches $)$ were collected from the middle portion of a dormant cane at $100-\mathrm{h}$ intervals of chilling starting at $200 \mathrm{~h}$ and reaching up to $800 \mathrm{~h}$.

Treatments. At each sampling date, 10 randomly chosen replication cuttings of each cultivar were rinsed with distilled water and placed in $\mathrm{l}-\mathrm{L}$ plastic beakers with the basal 3-4 inches in $5 \%$ sucrose solution. The solution was replaced every $3 \mathrm{~d}$. The basal part of the cuttings was recut each week to make sure that the vascular system was not clogged.

The cuttings were maintained in three growth chambers with photoperiods of 8,16 , and $24 \mathrm{~h}$ and temperature of $25 \pm 1{ }^{\circ} \mathrm{C}$ under cool white fluorescent tubes (200 $\mu \mathrm{mol} \cdot \mathrm{m}^{-2} \cdot \mathrm{s}^{-1}$ ) with a constant relative humidity of $70 \%$. Another group of cuttings was maintained in a greenhouse with ambient sunlight, average daylength of 10.5-13 h from starting experiment until termination $[8 \mathrm{Dec}$. 2017 to 4 May 2018 (average = $12 \mathrm{~h}$ )], and $25 \pm 3{ }^{\circ} \mathrm{C}$ constant daily temperature.

DETERMINING CHILLING REQUIREMENTS. Cuttings were monitored every day for chilling fulfillment and budbreak rate. We defined budbreak as the day when at least one bud on a cutting had reached stage 3 (green foliage) at 4 weeks of exposure to the forcing growth conditions (24 to $25^{\circ} \mathrm{C}$ ). In previous studies, budbreak and chilling fulfillment were evaluated within a 4 -week time period (Londo and Johnson, 2014), meaning dormancy was fulfilled and budbreak occurred when at least one bud on a cutting had reached stage 3 (green foliage) (Heide, 1993b). We removed the cuttings from the beakers once budbreak was recorded to prevent duplicate observation. Cuttings that remained in the beakers after 8 weeks without budbreak were dissected with a razor blade to determine if the bud was alive or dead. If the bud was viable, we considered it a dormant bud that needed more chilling hours.

Statistical analysis. The experimental design was a completely randomized design with each treatment replicated 10 times using one cutting per replication. Data were analyzed by analysis of variance $(P<$ 0.05 ) using JMP (version 9.0; SAS Institute, Cary, NC) with the fit model procedure. Correlations were estimated by restricted maximum likelihood using the multivariate procedure, and pairwise correlation was tested by Pearson's correlation coefficient.

\section{Results and discussion}

The accumulated chilling hours and budbreak of three grapes are presented in Fig. 1. All cultivars responded similarly to chilling treatments. All three cultivars needed a minimum of $600 \mathrm{~h}$ chilling to break their buds within 4 weeks of warm growing conditions. Accordingly, they are classified as low-chill, having $<1000 \mathrm{~h}$ of chilling required (Londo and Johnson, 2014). The general pattern of reduction in days to budbreak by increasing chilling hours was observed in this study (Fig. 1). 'MidSouth', 'Lake Emerald', and 'Blanc du bois' needed 14, 16, and $17 \mathrm{~d}$, respectively, to budbreak after their chilling requirements were fully satisfied at $600 \mathrm{~h}$ (Table 1; Fig. 1). The variation in budbreak rate was observed among the cultivars tested in this study once their chilling requirements were fulfilled (Table 1). 'MidSouth' had an average budbreak rate of $90 \%$ in all photoperiod treatments when exposed to at least $600 \mathrm{~h}$ chilling, $28 \%$ and $25 \%$ more than 'Blanc du bois' and 'Lake Emerald', respectively. 'Blanc du bois', 'Lake Emerald', and 'MidSouth' had accelerated rate of budbreak from 17, 16, and $14 \mathrm{~d}$ at $600 \mathrm{~h}$ chilling, respectively, to 


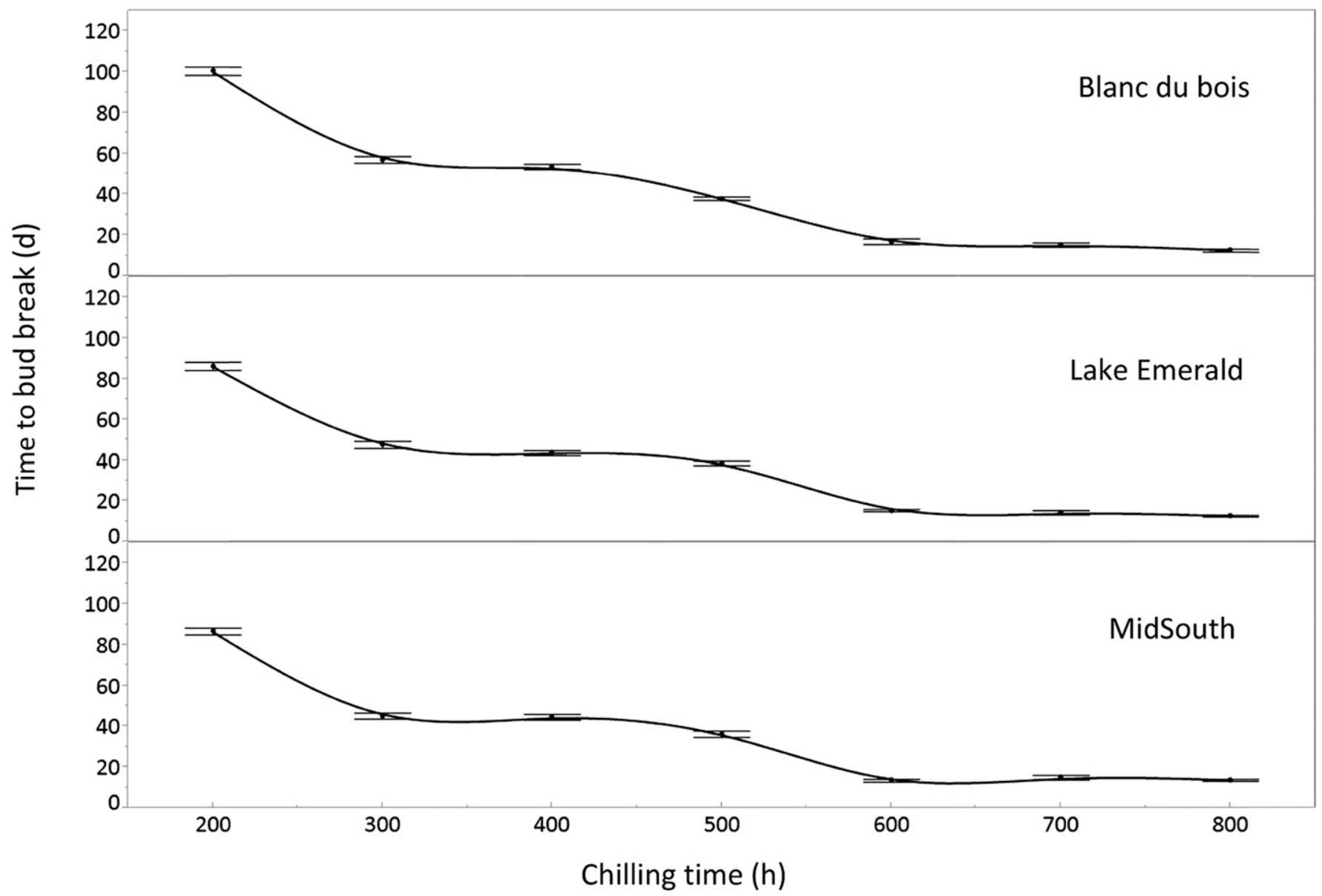

Fig. 1. Mean number of days $( \pm S E)$ required for budbreak and accumulated chilling hours for three interspecific hybrid grape cultivars. Days to budbreak decreased with increased chilling hours.

Table 1. Summary of three interspecific hybrid grape cultivars after receiving different chilling. Chilling requirement indicates the number of hours needed for budbreak within 4 wk of exposure to warm growing conditions [ $\left.77^{\circ} \mathrm{F}\left(25.0{ }^{\circ} \mathrm{C}\right)\right]^{\circ}$

\begin{tabular}{|c|c|c|c|c|}
\hline Cultivar & $\begin{array}{c}\text { Minimum time to } \\
\text { budbreak }[\text { mean } \pm \text { SE }(d)]^{\mathrm{z}}\end{array}$ & $\begin{array}{c}\text { Maximum } \\
\text { budbreak rate }(\%)^{y}\end{array}$ & $\begin{array}{l}\text { Avg time to budbreak } \\
{[\text { mean } \pm \text { SE }(d)]^{\mathrm{x}}}\end{array}$ & $\begin{array}{c}\text { Avg budbreak } \\
\text { rate }(\%)^{\text {w }} \\
\end{array}$ \\
\hline Blanc du bois & $12 \pm 0.7$ & 70 & $17 \pm 1.4$ & 62 \\
\hline MidSouth & $11 \pm 0.9$ & 100 & $14 \pm 0.7$ & 90 \\
\hline
\end{tabular}

${ }^{\mathrm{z}}$ Minimum time for maximum budbreak indicates the minimum number of days required to burst after receiving $800 \mathrm{~h}$ chilling under 24 -h photoperiod.

${ }^{\mathrm{y}}$ Maximum budbreak rate indicates maximum budbreak percentage at $600 \mathrm{~h}$ chilling in all photoperiod treatments.

${ }^{\mathrm{x}}$ Average time to budbreak indicates the mean number of days required for breaking bud after $600 \mathrm{~h}$ chilling.

wAverage budbreak rate indicates the mean budbreak percentage at $600 \mathrm{~h}$ chilling in all photoperiod treatments.

13,13 , and $13 \mathrm{~d}$ at $800 \mathrm{~h}$ (Table 1 ; Fig. 1).

Overall, cuttings subjected to natural photoperiod in a greenhouse (average $=12 \mathrm{~h}$ ) showed later budbreak compared with cuttings subjected to longer photoperiods in growth chambers [ 16 and $24 \mathrm{~h}$ (Table $2)$ ]. However, there was no significant difference between days to budbreak in response to daylength.

An interaction between photoperiod and chilling hour was observed on days to budbreak, although the three cultivars responded to two treatments differently. The interaction was most pronounced in 'MidSouth'. Among the treatments tested, a combination of 24-h photoperiod and chilling of $600 \mathrm{~h}$ resulted in a maximum budbreak rate of $70 \%$, $80 \%$, and $100 \%$ in 'Blanc du bois', 'Lake Emerald', and 'MidSouth', respectively (data not shown).

Our results indicated a weak, negative correlation between photoperiod and days to budbreak $(P=0.005, r=$ -0.116 ). Budbreak was delayed in short days compared with long days. A longer photoperiod reduced the days to budbreak (Table 2). 'Blanc du bois', 'Lake Emerald', and 'MidSouth' exposed to $600 \mathrm{~h}$ of chilling and 8-h photoperiod needed 27,19 , and $19 \mathrm{~d}$ to reach budbreak, respectively, whereas a longer photoperiod $(24 \mathrm{~h})$ reduced time to budbreak to 13,13 , and $11 \mathrm{~d}$, respectively (Table 2; Fig. 2). The results showed that cuttings were more 
Research Reports

Table 2. Effect of daylength and chilling hours on days to budbreak in three interspecific hybrid grape cultivars. There is a significant interaction $(P<0.0001)$ between photoperiod and chilling hours on time to budbreak within each cultivar.

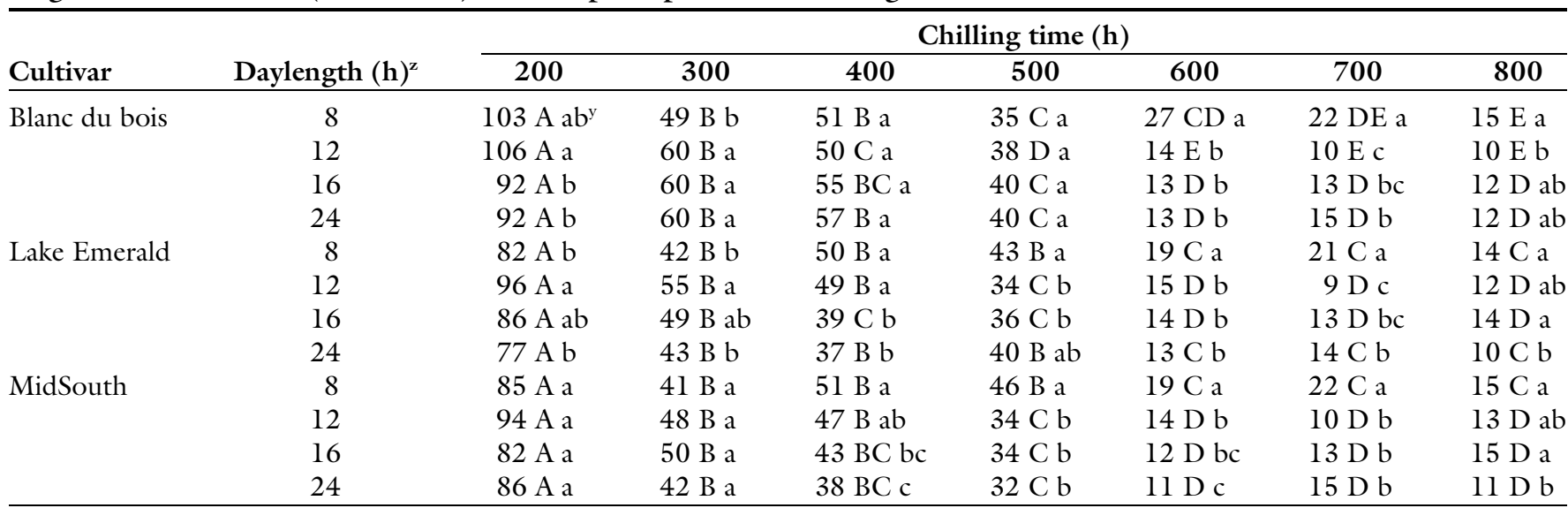

${ }^{\mathrm{z}} 8-$, 16-, and 24-h treatments were in a growth chamber; 12 -h treatment was in a greenhouse.

${ }^{y}$ Mean separation is within cultivars. Significant differences among chilling hours within cultivar are indicated by uppercase letters. Significant differences among photoperiods are indicated by lowercase letters. Means not followed by the same letters are significantly different $(P<0.05)$ and separated by Tukey's honestly significant difference.

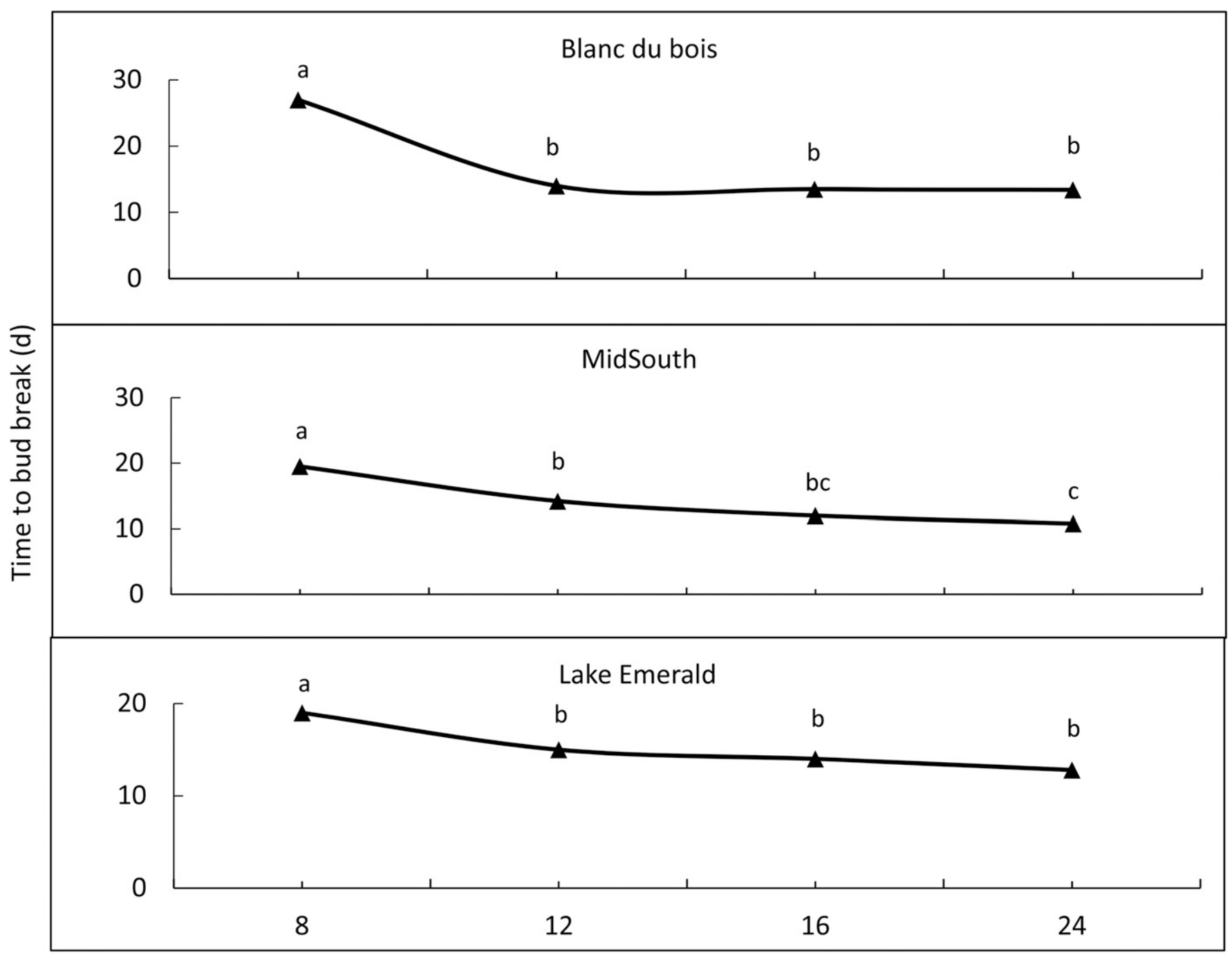

Photoperiod (h)

Fig. 2. Effect of different photoperiods on days to budbreak after $600 \mathrm{~h}$ chilling in three interspecific hybrid grape cultivars. Means within cultivar not followed by the same letters are significantly different $(P<0.05)$ and separated by Tukey's honestly significant difference. 
responsive to photoperiods at lower chilling such as $200 \mathrm{~h}$. The longest photoperiod $(24 \mathrm{~h})$ at $600 \mathrm{~h}$ chilling shortened days to budbreak by 14 , 6 , and $8 \mathrm{~d}$ in 'Blanc du bois', 'Lake Emerald', and 'MidSouth', respectively, whereas when they were exposed to $500 \mathrm{~h}$ chilling, the longest days ( $24 \mathrm{~h})$ decreased time to budbreak in 'Lake Emerald' and 'MidSouth' by 3 and $14 \mathrm{~d}$, respectively, and increased $5 \mathrm{~d}$ in 'Blanc du bois'. There are several reports on the effects of photoperiod on bud development during the winter chilling accumulation period in other crops. For example, Heide (1993a) suggested that long days reduced the time to budbreak in common hazel (Corylus avellana). Falusi and Calamassi (1996) reported that long days may substitute for winter chilling in european beech seedlings. In other words, in some species long days may reduce time to budbreak if the chilling requirement is inadequate to break the buds. Caffarra and Donnelly (2011) also concluded that long days are more effective for budbreak when the chilling requirement was not sufficient. In our study, only 'MidSouth' was responsive to photoperiod when the chilling requirement was less than $600 \mathrm{~h}$, but greater than $300 \mathrm{~h}$ (Table 2), meaning that this cultivar may also be sensitive to daylength changes before budbreak.

Garber (1983) showed once the chilling requirement for budbreak was met in loblolly pine, the photoperiod did not affect the rate of budbreak. However, Hellmers and Hesketh (1974) and Heide (1993b) reported that budbreak rate is controlled by both photoperiod and temperature in loblolly pine and european beech, respectively, even after chilling fulfillment. This result was in agreement with the previous study carried out by Grant (2012) who observed $100 \%$ budbreak on grape cultivars exposed to long days and forcing conditions. However, those which were exposed to short days showed $40 \%$ to $80 \%$ less budbreak. Fennell and Hoover (1991b) also found that long days shortened time to budbreak in fox grape (Vitis labrusca) and riverbank grape (Vitis riparia). Our results for these hybrid grape cultivars indicate that photoperiod influenced budbreak on lower chilling hours. All grapes in this study are grown in the southern United States where daylengths are shorter than in more northern latitudes. Moving these cultivars farther north where daylengths are longer could affect budbreak timing, potentially leading to frost and freeze injury.

This study showed that both chilling and photoperiod may be needed for induction of budbreak and breaking dormancy in these three grape cultivars. The results suggest that photoperiod plays only a minor role in induction of breaking dormancy compared with chilling accumulation. Also, different sensitivity to photoperiod was observed among the cultivars tested in this study that may affect the response of these cultivars to different climates. Thus, the actual significance of photoperiod may be over- or underestimated in this study because the results obtained from constant photoperiod and temperature in a controlled environment with cuttings may not reflect the actual response of adult grape exposed to environmental factors in the vineyard. It is still unclear whether longer days reduce forcing temperature or make plants more responsive to warmer conditions. Studies investigating global effects on grape suggested that chilling hours may be severely reduced in the future, especially in warm growing regions (Baldocchi and Wong, 2008; Luedeling et al., 2012). Understanding the chilling requirements of different grape cultivars will allow producers to determine the best fit for their growing region and prepare them to choose sustainable strategies over using artificial means to induce budbreak as a way to deal with progressing warmer climate conditions. Therefore, selection of cultivars with higher sensitivity to longer photoperiods to promote later budbreak may be a worthwhile strategy for breeders to introduce cultivars with higher bud dormancy stability in winter and better avoidance of spring frost injury.

\section{Literature cited}

Arora, R., L. Rowland, and K. Tanino. 2003. Induction and release of bud dormancy in woody perennials: A science comes of age. HortScience 38:911-921.

Baldocchi, D. and S. Wong. 2008. Accumulated winter chill is decreasing in the fruit growing regions of California. Clim. Change 87:S153-S166.
Bennett, J.P. 1949. Temperature and bud rest period. Calif. Agr. 3(11):9-12.

Caffarra, A. and A. Donnelly. 2011. The ecological significance of phenology in four different tree species: Effects of light and temperature on bud burst. Intl. J. Biometeorol. 55:711-721.

Dokoozlian, N.K. 1999. Chilling temperature and duration interact on the bud break of 'Perlette' grapevine cuttings. HortScience 34:1054-1056.

Dokoozlian, N.K., L.E. Williams, and R.A. Neja. 1995. Chilling exposure and hydrogen cyanimide interact in breaking dormancy of grape buds. HortScience 30:1244-1247.

Falusi, M. and R. Calamassi. 1996. Geographic variation and bud dormancy in beech seedlings (Fagus sylvatica). Ann. Sci. For. 53:967-979.

Fennell, A. and E. Hoover. 1991a. Morphological, physiological and dormancy responses of three Vitis genotypes to short photoperiod. Physiol. Plant. 109:203-210.

Fennell, A. and E. Hoover. 1991b. Photoperiod influences growth, bud dormancy, and cold acclimation in Vitis labruscana and Vitis riparia. J. Amer. Soc. Hort. Sci. 116:270-273.

Garber, M.P. 1983. Effects of chilling and photoperiod on dormancy release of container grown loblolly pine seedlings. Can. J. For. Res. 13:1265-1270.

Grant, T.N.L. 2012. Characterization of cold and short day acclimation in grape genotypes of contrasting freezing tolerance. Ohio State Univ., Columbus, $\mathrm{OH}$, PhD Diss.

Häkkinen, R., T. Linkosalo, and P. Hari. 1998. Effects of dormancy and environmental factors on timing of bud burst in Betula pendula. Tree Physiol. 18:707712.

Hanninen, H., M. Slaney, and S. Linder. 2007. Dormancy release of Norway spruce under climatic warming: Testing ecophysiological models of bud burst with a whole-tree chamber experiment. Tree Physiol. 27:291-300.

Hannah, L., P.R. Roehrdanz, M. Ikegami, A.V. Shepard, M.R. Shaw, G. Tabor, L. Zhi, P.A. Marquet, and R. Hijmans. 2013. Climate change, wine, and conservation. Proc. Natl. Acad. Sci. USA 110:69076912.

Heggie, L. and K.J. Halliday. 2005. The highs and lows of plant life: Temperature and light interactions in development. Intl. J. Dev. Biol. 49:675-687.

Heide, O.M. 1993a. Day length and thermal time responses of bud break 
during dormancy release in some northern deciduous trees. Physiol. Plant. 88:531-540.

Heide, O.M. 1993b. Dormancy release in beech buds (Fagus sylvatica) requires both chilling and long days. Physiol. Plant. 89:187-191.

Hellmers, H. and J.D. Hesketh. 1974. Phytotronics and modeling plant growth, p. 637-644. In: R.E. Buarski, A.R. Ferguson, and M.M. Creswell (eds.). Mechanisms of regulation of plant growth. Royal Soc. N.Z. Bul. 12.

Hunter, A.F. and M.J. Lechowicz. 1992. Predicting the timing of bud break in temperate trees. J. Appl. Ecol. 29:597604.

Körner, C. and D. Basler. 2010. Phenology under global warming. Science 327:1461-1462.

Lavee, S. and P. May. 1997. Dormancy of grapevine buds-Facts and speculation. Austral. J. Grape Wine Res. 3:31-46.

Li, C.Y., T. Puhakainen, A. Welling, A. Vihera-Aarnio, A. Ernstsen, O. Junttila, P. Heino, and E.T. Pavla. 2002. Cold acclimation in silver birch (Betula pendula). Development of freezing tolerance in different tissues and climatic ecotypes. Physiol. Plant. 116:478-488.

Londo, J.P. and L.M. Johnson. 2014. Variation in the chilling requirement and bud break rate of wild Vitis species. Environ. Expt. Bot. 106:138-147.

Luedeling, E., E.H. Girvetz, M.A. Semenov, and P.H. Brown. 2012. Climate change affects winter chill for temperate fruit and nut trees. PLoS One 6:e20155.

Mortenson, J.A. 1987. Blanc du Bois: A Florida bunch grape for white wine. Univ. Florida Agr. Expt. Sta., Inst. Food Agr. Sci. Circ. S-340.

Myking, T. and O.M. Heide. 1995. Dormancy release and chilling requirement of buds of latitudinal ecotypes of Betula pendula and Betula pubescens. Tree Physiol. 15:697-704.

Or, E. 2009. Grape bud dormancy release, p. 1-29. In: K.A. RoubelakisAngelakis (ed.). Grapevine molecular physiology and biotechnology. 2nd ed. Springer, Dordrecht, The Netherlands.

Overcash, J.P., C.P. Hegwood, Jr., and B.J. Stojanovic. 1981. 'MidSouth' and 'MissBlue'-Two new bunch grape cultivars. Mississippi Agr. For. Expt. Sta. Res. Rpt. 6(18).

Salzman, R.A., R.A. Bressan, P.M. Hasegawa, E.N. Ashworth, and B.P. Bordelon. 1996. Programmed accumulation of LEA-like proteins during desiccation and cold acclimation of overwintering grape buds. Plant Cell Environ. 19:713-720.

Sanz-Pérez, V., P. Castro- Díez, and F. Valladares. 2009. Differential and interactive effects of temperature and photoperiod on bud break and carbon reserves in two co-occurring Mediterranean oaks. Plant Biol. 11:142-151.
Stafne, E.T. and K. Alexander. 2017. A web-based chill hours app for fruit growers. J. Ext. 55(6):6TOT11. 5 Oct. 2018. <https://www.joe.org/joe/ 2017 december/ttll.php $>$.

Stover, L.H. 1954. The Lake Emerald grape. Univ. Florida Agr. Expt. Sta. Circ. S-68.

U.S. Department of Agriculture. 2018. USDA plant hardiness zone map. 5 Oct. 2018. <https://planthardiness.ars.usda. gov/PHZMWeb>.

Wake, C.M.F. and A. Fennell. 2000. Morphological, physiological and dormancy responses of three Vitis genotypes to short photoperiod. Physiol. Plant. 109:203-210.

Weinberger, J.H. 1950. Chilling requirements of peach varieties. Proc. Amer. Soc. Hort. Sci. 56:122-128.

Welling, A., T. Moritz, E.T. Palva, and O. Junttila. 2002. Independent activation of cold acclimation by low temperature and short photoperiod in hybrid aspen. Plant Physiol. 129:1633-1641.

Wareing, R.F. 1953. Growth studies in woody species. V. Photoperiodism in dormant buds of Fagus sylvatica L. Physiol. Plant. 6:692-706. 